\title{
KONSEP PENATAAN TRANSPORTASI (STUDI KASUS: TERMINAL PURABAYA, SURABAYA-SIDOARJO)
}

\author{
Siti Nuurlaily Rukmana ${ }^{1)}$, Lilatul Maghfiroh ${ }^{1)}$ dan Sofyan Efendi ${ }^{1)}$ \\ 1) Program Studi Perencanaan Wilayah dan Kota; Fakultas Teknik Sipil dan Perencanaan Kota \\ Universitas PGRI Adi Buana Surabaya \\ Email : nuurlailyrukmana@gmail.com
}

\begin{abstract}
Abstrak
Sistem tramportasi memiliki komponen utama yaitu jaringan jalan, terminal dan sarana transportasi. Penelitian ini fokus pada penataan terminal Purabaya, Surabaya-Sidoarjo. Isu-isu yang ada di terminal Purabaya yaitu kurang optimalnya kinerja operasiona terminal seperti fasilitas penunjang dan masih adanya kemacetan di pintu keluar terminal. Tujuan dari penelitian ini (1) Menganalisis tingkat pelayanan jalan di sekitar terminal (2) Mengevaluasi kinerja operasional terminal, dan (3)Menganalisis potensi dan masalah di kawasan terminal. Proses analisis ini dapat dilakukan dengan menggunakan metode analisis deskriptif kuantitatif dan deskriptif evaluatif. Hasil dari analisis penelitian ini bahwa: Pertama, tingkat pelayanan jalan di sekitar terminal adalah " $F$ " yang artinya terjadi antrian kendaraan yang panjang, Kedua, Berdasarkan hasil evaluasi kinerja terminal Purabaya bahwa saat ini kondis fasilitas baik dimana $90 \%$ untuk fasilitas utama dan $80 \%$ fasilitas penunjang. Ketiga, potensi dan masalah yang terjadi di wilayah studi yaitu tidak hanya letaknya yang strategis tetapi juga pada dampak terjadinya kemacetan dan kondisi fasilitas yang beberapa belum optimal. Oleh karena itu, konsep yang ditawarkan adalah penggunaan traffic light, pembangunan jalur khusus untuk bus.
\end{abstract}

\section{Kata kunci : Kemacetan, Terminal, Transportasi}

\begin{abstract}
Transportation system has the main component such as road network, terminal and its facilities. This research focuses on Purabaya Terminal, Surabaya-Sidoarjo. Today, the issues on Terminal is currently better than before. However, the operational performance is still not well i.e a congestion at the exit terminal. To achived this research, there are some objective such as (1) Analyzing the level of service (2) evaluating the terminal operational performance and (3)analyzing the potentials and problems. The method of this research is descriptive - quantitative dan descriptiveevaluative. Therefore, the results of this research are: $1^{\text {st }}$, the level of service in surronding Purabaya Terminal is " $F$ ". It means that the amount of congestion is high. $2^{\text {nd }}$, Based on analysis, the terminal operational performance is well such as $90 \%$ for main facility and $80 \%$ for supporting faciity. $3^{\text {rd, }}$ the result of potentials and problems in this study focus on congestion and facilitate. So, the concepts of this research are using a traffic light and constructing a special line for buses.
\end{abstract}

Keywords: Congestion, Terminal, Transportation 


\section{PENDAHULUAN}

Tujuan dari transportasi ini yaitu untuk memberikan mobilitas baik barang/orang guna melakukan aktifitasnya. Aktifitas disini salah satunya yaitu pergerakan orang dari rumah ke tempat kerja, pendidikan, dll. Selain itu, menurut (Iles, 2005) bahwa transportasi tidak hanya digunakan untuk memindahkan orang dari tempat tinggalnya ke tempat aktivitasnya tetapi juga memindahkan barang dari tempat produksi ke tempat yang dibutuhkan.

Sistem tramportasi memiliki komponen utama yaitu jaringan jalan, terminal dan sarana transportasi yaitu berupa jenis kendaraan (Kodoatie, 2003). Penelitian ini hanya fokus pada terminal. Menurut definisinya terminal merupakan suatu stasiun tempat pemberangkatan atau pemberhentian terakhir atau persinggahan kendaraan lain seperti kereta api, pesawat, dll (Adisasmita, 2014). Fungsi utama dari terminal adalah menyediakan fasilitas untuk masuk dan keluar bagi penumpang maupun barang menuju dan dari suatu sistem transportasi.

Terminal Purabaya (Bungurasih) secara administrasi terletak di Kecamatan Waru Kabupaten Sidoarjo. Dipilihnya lokasi tersebut karena memiliki akses yang strategis yaitu sebagai pintu masuk ke kota Surabaya serta berada pada jalur keluar kota Surabaya arah timur selatan dan barat. Hal ini yang disebut terminal sebagai sarana penghubung transportasi (Khisty, 2005). Sistem pengelolahan Terminal Purabaya yaitu dilakukan oleh Pemerintah Kota Surabaya. Berdasarkan Perda Kota Surabaya No 12/2014 bahwa terminal ini merupakan tipe A dengan luas lahan $12 \mathrm{~km}^{2}$, dimana melayani Angkutan Antar Kota Antar Propinsi (AKAP), Angkutan Antar Kota Dalam Propinsi (AKDP), dan Angkutan Kota.

Permasalahan-permasalahan yang sering muncul dalam terminal biasanya berupa kurang optimalnya fasilitas penunjang dan terjadinya kemacetan yang disebabkan adanya penumpukan bus khususnya di pintu keluar Terminal Purabaya.

Tujuan penelitian ini (1) menganalisis tingkat pelayanan lalu lintas di sekitar terminal Purabaya (2) Menganalis evaluasi kinerja operasional terminal dan (3) analisis potensi \& masalah terminal Purabaya. Penelitian ini fokus pada Terminal Purabaya (Gambar 1), dimana secara administrasi sebagai berikut:

Utara : Kelurahan Dukuh Menanggal

Timur : Kelurahan Gedungrejo

Selatan : Kelurahan Medaeng

Barat : Kelurahan Bungurasih

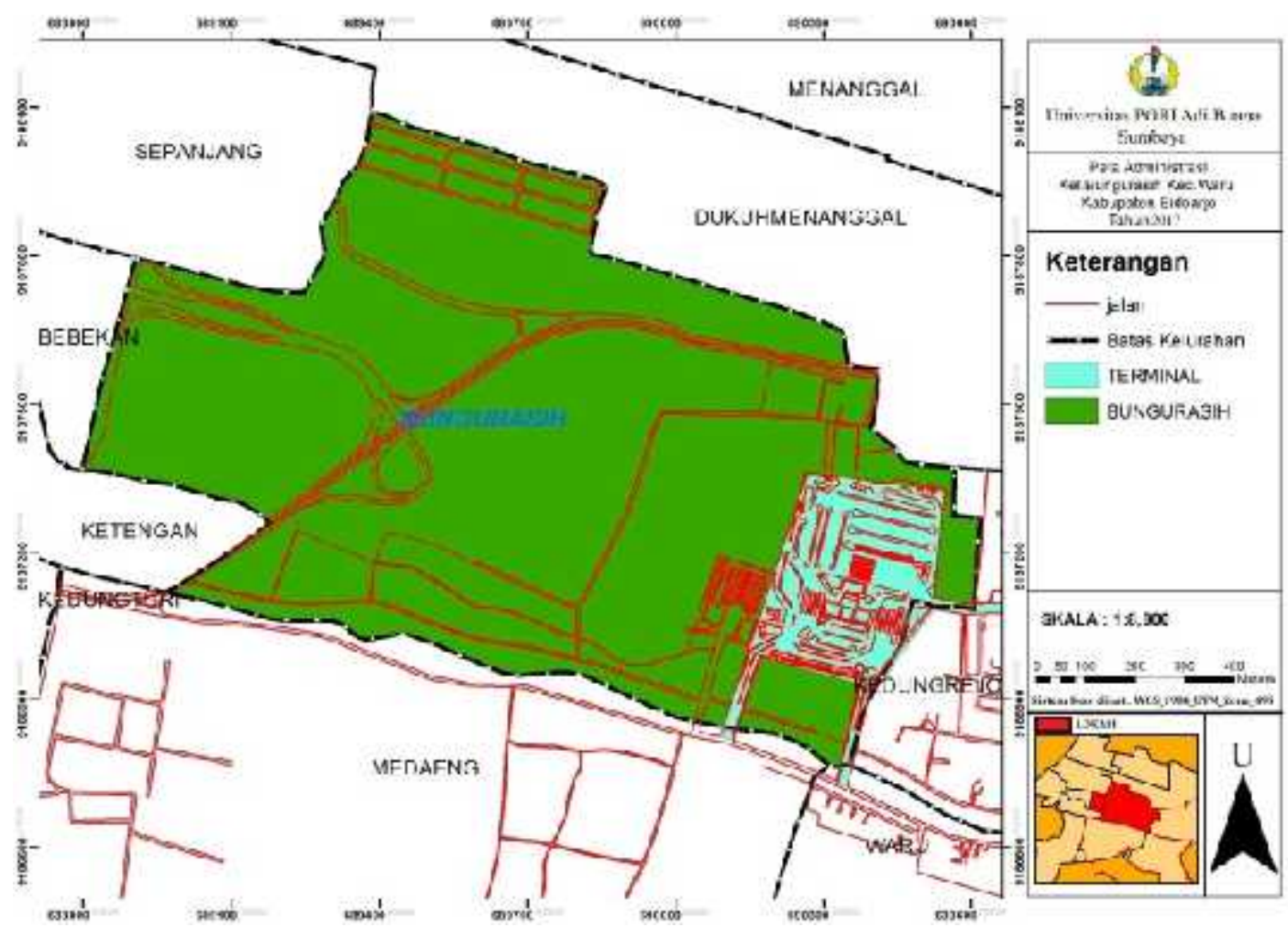

Gambar 1. Peta Administrasi Wilayah Studi 
Siti Nuurlaily Rukmana, Lailatul Maghfiroh dan Sofyan Efendi: Konsep Penataan Transportasi (Studi kasus: Terminal Purabaya, Surabaya-Sidoarjo)

\section{METODE}

\section{Pengumpulan Kebutuhan Data}

Pengumpulan data merupakan

serangkaian data-data yang diperlukan untuk melakukan analis sehingga dapat mencapai tujuan yang diharapkan. Pengumpulan kebutuhan data dapat dilihat pada tabel 1:

Tabel 1 Pengumpulan Kebutuhan Data

\begin{tabular}{cll}
\hline NO & \multicolumn{1}{c}{ JENIS DATA } & \multicolumn{1}{c}{ MEDIA } \\
\hline 1. & Dokumentasi/Foto Mapping & Observasi \\
2. & Data kondisi fisik terminal & Observasi \\
3. & Data sistem jaringan jalan & Observasi \\
& $\begin{array}{l}\text { a. Ruas jalan } \\
\text { b. Volume kendaraan }\end{array}$ & \\
4. & Data kinerja operasional terminal & a. Observasi \\
& a. Kesesuaian lokasi & b. Wawancara \\
b. Kapasitas terminal & c. Kuesioner \\
& c. Waktu tunggu penumpang & \\
d. Waktu tunggu kendaraan & \\
e. Kesesuaian fasilitas terminal & \\
f. Sirkulasi terminal & \\
g. Kelembagaan & \\
\hline
\end{tabular}

2. Metode Analisis

Metode analisis ini merupakan tindak lanjuk dari pengumpulan data, dimana dalam kegiatan ini merupakan tahapan untuk menganalisis data. Untuk lebih jelasnya terkait dengan metode analisis dapat dilihat di tabel 2

Tabel 2 Metode Analisis

\begin{tabular}{lll}
\hline \multicolumn{1}{c}{ Sasaran Penelitian } & \multicolumn{1}{c}{ Teknik } & \multicolumn{1}{c}{ Output } \\
\hline $\begin{array}{l}\text { Menghitung tingkat pelayanan } \\
\text { lalu lintas di sekitar terminal } \\
\text { Purabaya }\end{array}$ & Analisis deskriptif kuantitatif & $\begin{array}{l}\text { Mengetahui tingkat pelayahan } \\
\text { (LOS) lalu lintas di sekitar } \\
\text { terminal Purabaya }\end{array}$ \\
$\begin{array}{l}\text { Menganalisis dan menilai } \\
\text { tingkat kinerja operasional } \\
\text { terminal Purabaya }\end{array}$ & $\begin{array}{l}\text { Analisis deskriptif kuantitatif } \\
\text { dan deskriptif evaluatif }\end{array}$ & $\begin{array}{l}\text { Menghitung dan mengevaluasi } \\
\text { antara kondisi eksisting } \\
\text { dengan kebijakan yang ada }\end{array}$ \\
$\begin{array}{l}\text { Analisis potensi dan masalah di } \\
\text { terminal Purabaya }\end{array}$ & $\begin{array}{l}\text { Analisis deskriptif } \\
\text { menggunakan teknik analisis } \\
\text { SWOT }\end{array}$ & $\begin{array}{l}\text { Identifikasi potensi dan } \\
\text { permasalahan menggunakan } \\
\text { SWOT }\end{array}$ \\
\hline
\end{tabular}

\section{HASIL DAN PEMBAHASAN}

\section{Analisa Tingkat Pelayanan Jalan (Level of Service)}

Untuk menghitung tingkat kinerja jalan peneliti membagi menjadi 3 segmen untuk mempermudah pada saat pengambilan data. Segmen $1 \& 2$ berada di titik Jalan letjen Sutoyo dan segmen 3 yaitu berada di flyover waru sampai pada pintu keluar bus. Untuk lebih jelasnya dapat dilihat di Gambar 2 


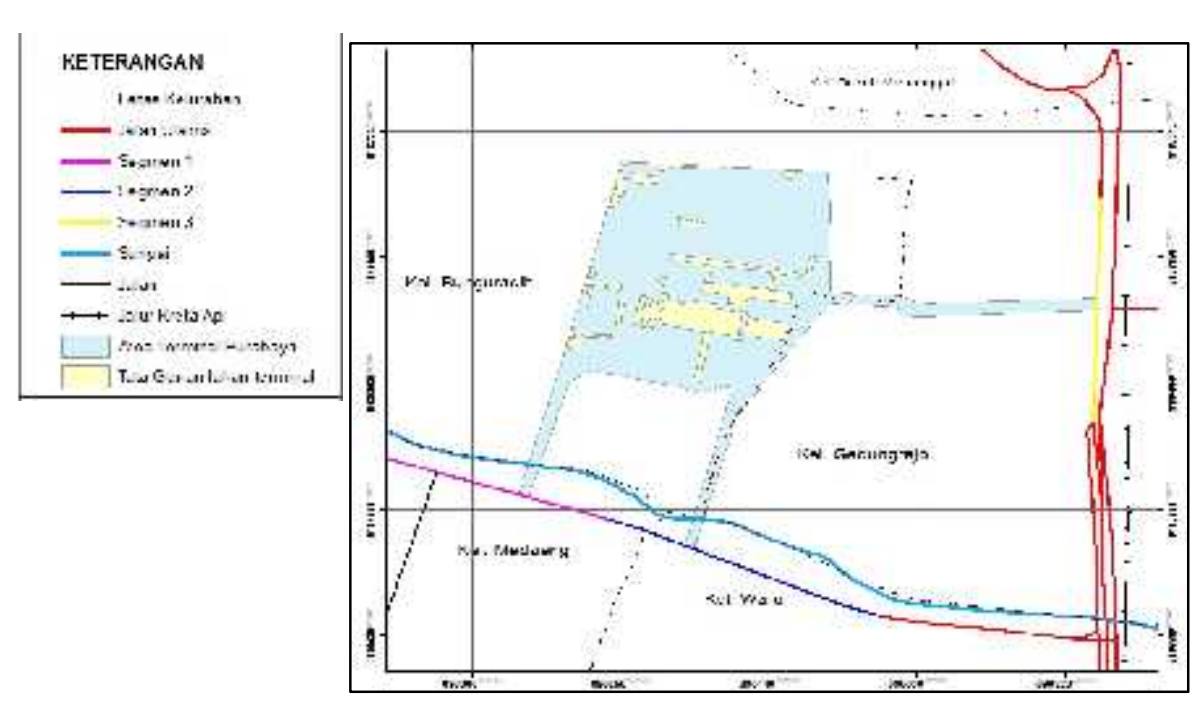

Gambar 2. Peta Pembagian Segmen

a. Kapasitas jalan

Kapasitas jalan adalah jumlah kendaraan maksimum yang dapat melewati suatu jalan pada jalur jalan selama 1 jam dengan kondisi serta arus lalu lintas tertentu.
Penghitungan kapasitas suatu ruas jalan perkotaan (MKJI 1997), yaitu $\mathrm{C}=\mathrm{Co} . \mathrm{FCw} . \mathrm{FCsp} . \mathrm{FCsf} . \mathrm{FCcs}$

Berikut dapat dilihat analisa tingkat kinerja jalan pada segmen 1,2 dan 3 :

1. Jalan Letjen Sutoyo (segmen I dan II, arah barat jalan Letjen Sutoyo (Medaeng) menuju sampai batas Flay over Waru Sidoarjo)

Tabel 2. Perhitungan Kapasitas Jalan (Segmen 1\&2)

\begin{tabular}{|c|c|c|c|c|c|}
\hline $\begin{array}{l}\text { Kpa } \\
\text { sitas } \\
\text { Das } \\
\text { ar } \\
\text { (Co) }\end{array}$ & $\begin{array}{l}\text { Penye } \\
\text { suaian } \\
\text { Lebar } \\
\text { Jalan } \\
\text { (FCw) }\end{array}$ & $\begin{array}{l}\text { Pemisa } \\
\text { han } \\
\text { Arah } \\
\text { (FCsp) }\end{array}$ & $\begin{array}{l}\text { Hambatan } \\
\text { Samping dan } \\
\text { Bahu Jalan } \\
\text { Efektif (FCsf) }\end{array}$ & $\begin{array}{l}\text { Faktor } \\
\text { Penyesuaia } \\
\text { n Ukuran } \\
\text { Kota } \\
\text { (FCes) }\end{array}$ & $\begin{array}{l}\text { Kapasit } \\
\text { as } \\
\text { Jalan } \\
\text { (C) }\end{array}$ \\
\hline 2900 & 1,08 & 1,00 & 0,85 & 1,00 & 2662 \\
\hline
\end{tabular}

2. Segmen III (Flyover Waru menuju arah utara sampai batas pintu keluar bus antar kota)

Tabel 3. Perhitungan Kapasitas Jalan (Segmen 3)

\begin{tabular}{|c|c|c|c|c|c|}
\hline $\begin{array}{l}\text { Kpasit } \\
\text { as } \\
\text { Dasar } \\
\text { (Co) }\end{array}$ & $\begin{array}{l}\text { Penyesuaia } \\
\text { n Lebar } \\
\text { Jalan } \\
(\text { FCw) }\end{array}$ & $\begin{array}{l}\text { Pemisa } \\
\text { han } \\
\text { Arah } \\
\text { (FCsp) }\end{array}$ & $\begin{array}{l}\text { Hambatan } \\
\text { Samping dan } \\
\text { Bahu Jalan } \\
\text { Efektif (FCsf) }\end{array}$ & $\begin{array}{l}\text { Faktor } \\
\text { Penyesuaian } \\
\text { Ukuran Kota } \\
\text { (FCcs) }\end{array}$ & $\begin{array}{l}\text { Kapas } \\
\text { itas } \\
\text { Jalan } \\
\text { (C) }\end{array}$ \\
\hline 6600 & 0,92 & 1,00 & 0,92 & 1,00 & 5586 \\
\hline
\end{tabular}

b. Tingkat Pelayanan Jalan (level of service)

Selanjutnya setelah menghitung kapasitas jalan, maka akan memperoleh tingkat pelayanan pada masing-masing segmen.Berikut dapat dilihat pada tabel 4. 
Siti Nuurlaily Rukmana, Lailatul Maghfiroh dan Sofyan Efendi: Konsep Penataan Transportasi (Studi kasus: Terminal Purabaya, Surabaya-Sidoarjo)

Tabel 4. Perhitungan Kapasitas Jalan (Segmen 3)

\begin{tabular}{|c|c|c|c|c|c|c|c|c|c|c|}
\hline \multirow[t]{2}{*}{ Lokasi } & \multicolumn{3}{|c|}{ Arus Total $(\mathbf{Q})$} & \multirow{2}{*}{$\begin{array}{l}\text { Kapasitas } \\
\text { Jalan (C) }\end{array}$} & \multicolumn{3}{|c|}{ Derajat Kejenuhan $(\mathrm{Q} / \mathrm{C})$} & \multicolumn{3}{|c|}{ LOS } \\
\hline & \multicolumn{8}{|c|}{ Jl. Letjen Sutoyo } & & Sore \\
\hline Segmen I & 7849 & 7116 & 7121 & 2662 & 2,9 & 2,7 & 2,7 & $\mathrm{~F}$ & $\mathrm{~F}$ & $\mathrm{~F}$ \\
\hline Segmen II & 5255 & 4701 & 5403 & & 2,0 & 1,8 & 2,0 & $\mathrm{~F}$ & $\mathrm{~F}$ & $\mathrm{~F}$ \\
\hline \multicolumn{11}{|c|}{ Jl. Waru Sidoarjo } \\
\hline $\begin{array}{l}\text { Segmen } \\
\text { III }\end{array}$ & 13068 & 8826 & 12314 & 5586 & 2,3 & 1,6 & 2,2 & $\mathrm{~F}$ & $\mathrm{~F}$ & $\mathrm{~F}$ \\
\hline
\end{tabular}

Sehingga berdasarkan hasil analisa bahwa tingkat pelayanan lalu lintas di wilayah studi yaitu "F". Artinya kondisi jalan memiliki arus lalu lintas yang tinggi atau macet. Biasayanya kecepatan kendaraan rendah karena terjadi antrian panjang di sekitar segmen tersebut.

\section{Analisa Evaluasi Kinerja Terminal}

Analisa evaluasi kinerja terminal pada penelitian ini fokus pada tingkat kesesuaian lokasi, ketersediaan fasilitas utama dan fasilitas penunjang. Berikut dapat dijelaskan dibawah ini:

a. Analisis Kesesuaian Lokasi

Proses analisis ini dengan cara membandingkan antara kondisi eksisting dengan Peraturan Menteri Perhubungan RI No 132/2015 Bab III Pasal 21. Berikut dapat dilihat di Tabel 5:

Tabel 5 Kesesuaian Eksisting dengan Persyaratan Terminal

\section{Permen Perhubungan RI No. PM 132 Kesesuaian Eksisting dengan Persyaratan}

\section{Tahun 2015 Bab III Pasal 21}

1. Terletak dalam jaringan trayek antar kota antar propinsi

2. Terletak di jalan arteri dengan kelas jalan III A

3. Jarak antara dua terminal tipe A sekurang-kurangnya $20 \mathrm{~km}$ di Pulau Jawa

4. Tersedia lahan sekurang-kurangnya 5 Ha untuk terminal di Pulau Jawa dan Sumatra, dan $3 \mathrm{Ha}$ untuk terminal di pulau lainnya.

5. Mempunyai akses jalan masuk atau keluar dan dari terminal dengan jarak sekurang-kurangnya $100 \mathrm{~m}$ di Pulau Jawa dan $50 \mathrm{~m}$ di pulau lainnya, dihitung dari jalan ke pintu keluar atau masuk terminal.
Sesuai, hal ini dilihat dari skala pelayanan diTerminal Purabaya yang melayani nus AKDP juga AKAP. Mis, pada jenis bus AKAP yaitu Surabaya-Jakarta. Surabaya-Bali, dll.

Sesuai, pada jalan arteri dengan kelas jalan tipe III A di Terminal Puarabaya terletak di Jalan Waru Sidoarjo.

Sesuai, pada jarak $44 \mathrm{~km}$ antara dua terminal tipe A di Pulau Jawa yaitu pada Kabupaten Mojokerto

Luas lahan Terminal Purabaya berdasrkan hasil survei UPTD Terminal Purabaya, luasnya hanya mencapai $12 \mathrm{Ha}$.

1. Akses jalan masuk ke Terminal Purabaya berjarak $\pm 150 \mathrm{~m}$ dari Jalan Letjen Sutoyo.

2. Sedangkan untuk akses jalur pemberangkatan di Terminal Purabaya terdapat dua jalur, jalur pemberangkatan bus AKDP dan AKAP dan jalur pemberangkatan bus dalam kota dan angkutan kota mikrolet.

3. Pintu keluar untuk bus AKDP dan AKAP yang terletak di sebelah barat terminal, bersinggungan langsung dengan Jalan Waru Sidoarjo dan pintu keluar untuk bus dalam kota dan angkutan kota mikrolet yang terletak di sebelah selatan bersinggungan langsung dengan Jalan Letjen Sutoyo. 
Siti Nuurlaily Rukmana, Lailatul Maghfiroh dan Sofyan Efendi: Konsep Penataan Transportasi (Studi kasus: Terminal Purabaya, Surabaya-Sidoarjo)

Berdasarkan tabel diatas, maka dapat disimpulkan bahwa Terminal Purabaya telah sesuai dengan Peraturan Menteri Perhubungan RI No 132/2015 dengan jumlah prosentase $100 \%$. Disamping itu juga menunjukkan bahwa Terminal Purabaya merupakan terminal tipe A. b. Analisis Kesusuaian Fasilitas Terminal Analisa ini dilakukan berdasarkan Peraturan Menteri Perhubungan RI No 132/2015 tentang Fasilitas Terminal Bab 5. Berikut dapat dilihat pada tabel 6:

Tabel 6 Kesesuaian Eksisting dengan Persyaratan Fasilitas Terminal

\begin{tabular}{|c|c|c|c|}
\hline No & \multicolumn{2}{|c|}{$\begin{array}{l}\text { Permen Republik Indonesia Nomor PM } \\
132 \text { Tahun } 2015\end{array}$} & $\begin{array}{l}\text { Kesesuaian Eksisting } \\
\text { dengan Persyaratan }\end{array}$ \\
\hline \multicolumn{4}{|c|}{ A. FASILITAS UTAMA } \\
\hline 1. & \multicolumn{2}{|c|}{ Jalur pemberangkatan kendaraan umum } & $\sqrt{ }$ \\
\hline 2. & \multicolumn{2}{|c|}{ Jalur kedatangan kendaraan umum } & $\sqrt{ }$ \\
\hline 3. & \multicolumn{2}{|c|}{$\begin{array}{l}\text { Tempat parkir kendaraan umum selama } \\
\text { menunggu keberangkatan, termasuk } \\
\text { didalamnya tempat tunggu dan tempat }\end{array}$} & $\sqrt{ }$ \\
\hline 4. & \multicolumn{2}{|c|}{$\begin{array}{l}\text { istirahat kendaraan umum } \\
\text { Menara pengawas }\end{array}$} & $\sqrt{ }$ \\
\hline 5. & \multicolumn{2}{|l|}{ Loket penjualan karcis } & $\sqrt{ }$ \\
\hline 6. & \multicolumn{2}{|l|}{ Loket retribusi ruang tunggu } & $\sqrt{ }$ \\
\hline 7. & \multicolumn{2}{|c|}{$\begin{array}{l}\text { Rambu-rambu dan papan informasi, yang } \\
\text { sekurang-kurangnya memuat petunjuk } \\
\text { jurusan, tarif dan jadwal perjalanan }\end{array}$} & $\sqrt{ }$ \\
\hline 8. & \multicolumn{2}{|c|}{$\begin{array}{l}\text { jurusan, tarif dan jadwal perjalanan } \\
\text { Pelataran parkir kendaraan pengantar } \\
\text { dan/atau taksi }\end{array}$} & $\sqrt{ }$ \\
\hline & \\
\hline 9 & \multicolumn{2}{|c|}{$\begin{array}{l}\text { B. FASILITAS PENUNJAN } \\
\text { Kmar kecil/toilet }\end{array}$} & $\sqrt{ }$ \\
\hline 10. & \multicolumn{2}{|l|}{ Musholla } & $\sqrt{ }$ \\
\hline 11. & \multicolumn{2}{|l|}{ Tempat istirahat Crew bus } & $\sqrt{ }$ \\
\hline 12. & \multicolumn{2}{|l|}{ Ruang pengobatan } & $\sqrt{ }$ \\
\hline 13. & \multicolumn{2}{|l|}{ Pos polisi/ Keamanan } & $\sqrt{ }$ \\
\hline 14. & \multicolumn{2}{|l|}{ Tempat pencucian kendaraan } & $\sqrt{ }$ \\
\hline 15 & \multicolumn{2}{|l|}{ Kios/kantin } & $\sqrt{ }$ \\
\hline 16. & \multicolumn{2}{|l|}{ Ruang informasi dan pengaduan } & $\sqrt{ }$ \\
\hline 17. & \multicolumn{2}{|l|}{ Telpon umum } & $\sqrt{ }$ \\
\hline 18 & \multicolumn{2}{|l|}{ Taman } & $\sqrt{ }$ \\
\hline \multirow{2}{*}{\multicolumn{4}{|c|}{$\begin{array}{ll}\text { Keterangan: } & \text { 1) Analisa potensi dan masalah } \\
\text { Berdasarkan tabel } 6 \text {, maka penggunaan } & \text { Pada analisa potensi masalah dilakukan } \\
\text { fasilitas utama yang telah sesuai dengan } & \text { dengan tujuan untuk mengakumulasi secara } \\
\text { Peraturan Menteri Perhubungan RI No } & \text { keseluruhan potensi dan masalah yang ada di } \\
132 / 2015 \text { sebesar } 90 \% \text { sedangkan untuk } & \text { wilayah studi. Berikut dapat dilihat pada tabe } \\
\text { fasilitas penunjang sebesar } 80 \% . & \end{array}$}} \\
\hline & & & \\
\hline \multicolumn{4}{|c|}{ Tabel 7 Analisa Potensi Masalah } \\
\hline \multicolumn{4}{|c|}{ Masalah } \\
\hline $\begin{array}{l}\text { Lokasi } \\
\text { terminal }\end{array}$ & $\begin{array}{l}\text { Potensi } \\
\text { Lokasi strategis terletak di jalan arteri } \\
\text { primer dan kolektor sekunder sehingga } \\
\text { akses untuk ke terminal dan visibility } \\
\text { terminal mudah dicapai }\end{array}$ & $\begin{array}{l}\text { sepanja } \\
\text { Jalan R } \\
\text { tidak la } \\
\text { terutam }\end{array}$ & $\begin{array}{l}\text { ing Jalan Letjen Sutoyo dan } \\
\text { aya Waru yang mengakibatkan } \\
\text { ncarmya arus kendaraan } \\
\text { la pada pagi dan sore }\end{array}$ \\
\hline $\begin{array}{l}\text { Operasiona } \\
1 \text { Terminal }\end{array}$ & $\begin{array}{l}\text { Sirkulasi kendaraan didalam yang jelas } \\
\text { dan teratur }\end{array}$ & $\begin{array}{l}\text { a. } \\
\text { membe } \\
\text { atau } \mathrm{m}\end{array}$ & $\begin{array}{l}\text { Banyak penumpang yang } \\
\text { rhentikan angkutan baik bus } \\
\text { ikrolet diluar lokasi terminal }\end{array}$ \\
\hline
\end{tabular}


Siti Nuurlaily Rukmana, Lailatul Maghfiroh dan Sofyan Efendi: Konsep Penataan Transportasi (Studi kasus: Terminal Purabaya, Surabaya-Sidoarjo)

\begin{tabular}{lll}
\hline Variabel & Potensi & Masalah \\
\hline $\begin{array}{ll}\text { Fasilitas } \\
\text { (sarana }\end{array}$ & Kelengkapan rambu-rambu diarea & b. Banyak angkutan yang menunggu \\
$\begin{array}{l}\text { prasarana) } \\
\text { terminal }\end{array}$ & Sistem drainase yang kurang baik \\
terminal sudah memadai & sehingga menyebabkan terjadinya \\
\hline
\end{tabular}

\section{2) Rekomendasi}

Berdasarkan hasil analisa sebelumnya, maka rekomendasi yang diberikan pada penelitian ini yaitu:

1. Rencana Perbaikan Kinerja Jalan Letjen Sutoyo (Segmen I dan II, arah barat Jalan Lerjen Sutoyo (Medaeng) menuju sampai batas Flay Over Waru Sido arjo) yang dapat dilihat pada gambar $3 \rightarrow$ Pemasangan Traffic light di pertigaan Mall/Swalayan Ramayana

2. Rencana Perbaikan Kinerja Jalan di segmen III (Gambar 4) $\rightarrow$ Penambahan jalur khusus untuk bus AKAP/AKDP di depan pintu keluar $\pm 300 \mathrm{~m}$ (hingga titik bundawaran waru)

3. Perbaikan/normalisasi saluran drainase dan penambahan inlet.

4. Peremajaan fasilitas terminal
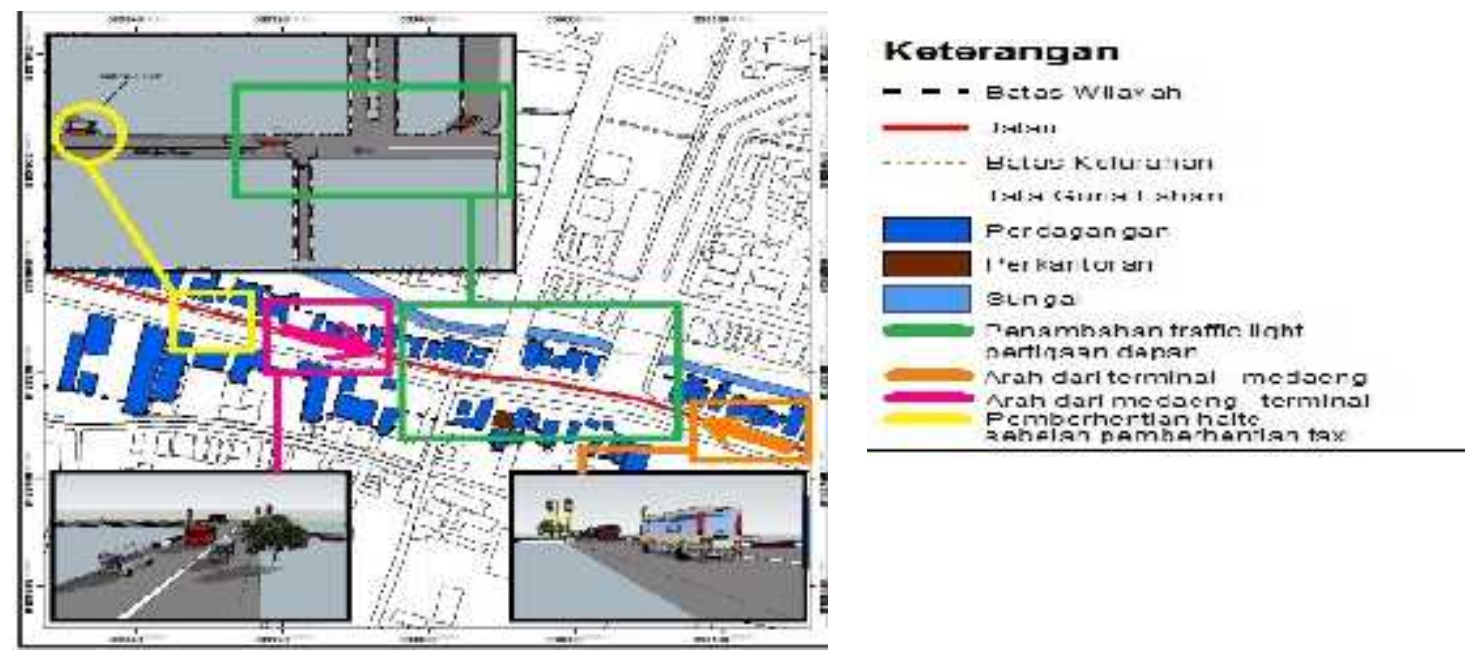

Gambar 3. Arahan rencana segmen I \& II

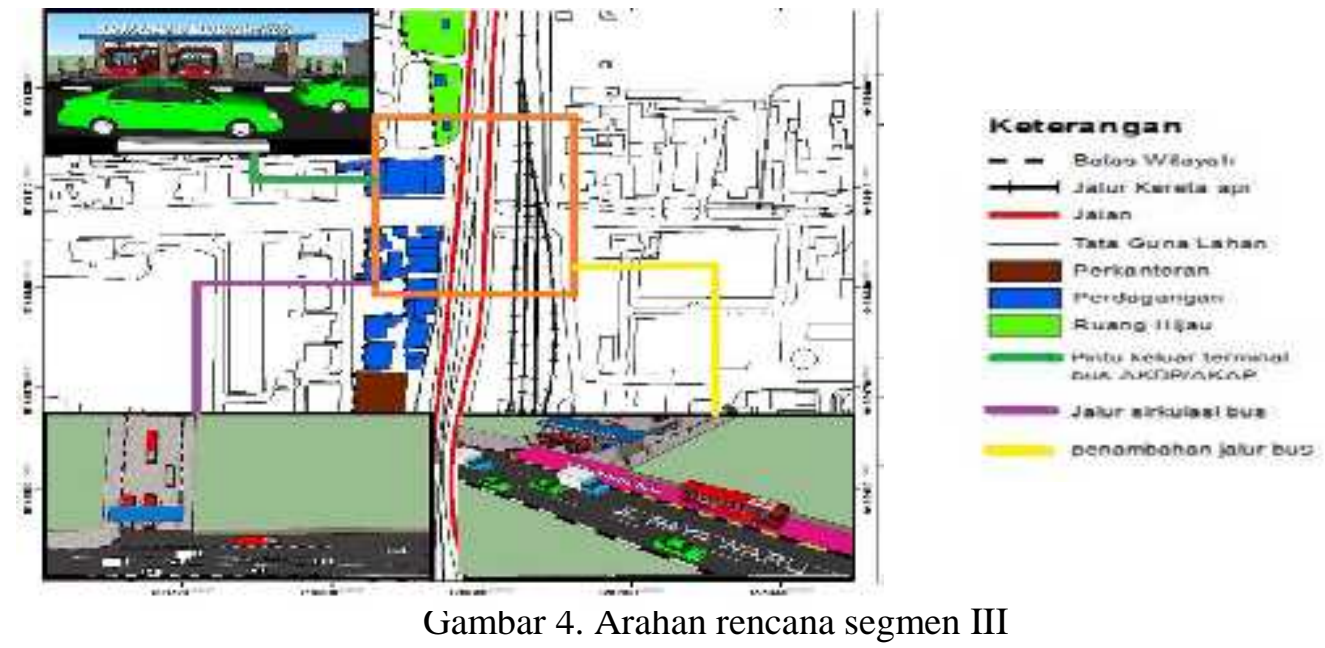




\section{KESIMPULAN}

Konsep penataan transportasi khusunya di terminal Purabaya dilakukan dengan beberapa cara yaitu berdasarkan analisis kinerja jalan disekitar terminal yaitu memiliki LOS "F" yang artinya pada ruas jalan tersebut terjadi kemacetan lalu lintas dimana memiliki antrian yang panjang. Sedangkan untuk evaluasi kinerja operasional yaitu untuk fasilitas utama 90\% kondisnya baik dan fasilitas penunjang $80 \%$ kondisinya baik. Sehingga berdasarkan hasil analisis maka arahan/rekomendasi yang diberikan pada penelitian ini yaitu dilakukan dengan 4 aspek yaitu: pemasangan (1) traffic light, (2) penambahan jalur khusus untuk bus AKAP/AKDP (3) normalisasi drainase \& penambahan inlet (4) serta peremajaan fasilitas terminal.

\section{UCAPAN TERIMAKASIH}

Studi Perencanaan Wilayah dan Kota, Fakultas Teknik Sipil dan Perencanaan, Universitas PGRI Adi Buana (UNIPA) Surabaya sebagai wadah pengembangan keilmuan.

\section{DAFTAR PUSTAKA}

Anonim. 2014. Peraturan Daerah No.12 Tahun 2014 tentang RTRW Kota Surabaya.

Surabaya: Pemerintah Kota SUrabaya

Adisasmita, R. (2014). Manajemen Pembangunan Transportasi i (I). Indonesia: Graha Ilmu.

C. Jotin Khisty, B. K. L. pd. (2005). Dasar-dasar rekayasa transportasi. (L. Simarmata, Ed.) (3rd ed.). Jakarta: Erlangga. Retrieved from

https://ebooktekniksipil.files.wordpress.com/2014/05/dasar-rekayasa-transportasi-jilid1.pdf

Direktorat Jenderal Bina Jalan Kota. (1997). Manual Kapasitas Jalan Indonesia. Jakarta.

Iles, R. (2005). Public Transport in Developing Countries (First Edit). Netherlands: Elsevier

Kodoatie, R. J. (2003). Manajemen Dan Rekayasa Infrastruktur. Yogyakarta - Indonesia: Pustaka Pelajar

Peraturan Menteri No 132. (2015). Penyelenggaraan Terminal Penumpang Angkutan Jalan. Jakarta: Menteri Perhubungan RI. 